\title{
HUBUNGAN ANTARA SUBJECTIVE WELL-BEING DENGAN HASIL BELAJAR BIOLOGI SISWA KELAS X SMA NURAIDA ISLAMIC BOARDING SCHOOL (NIBS) BOGOR
}

\author{
Zakiyah \\ Magister Teknologi Pendidikan Sekolah Pascasarjana UIKA Bogor \\ zakiyah0106@gmail.com
}

\begin{abstract}
Abstrak : Penelitian ini bertujuan untuk mengetahui dan menguji teori hubungan antara Kecerdasan Intelektual dan subjective well-being siswa terhadap hasil belajar Biologi siswa kelas X SMA Nuraida Islamic Boarding School Kota Bogor. Masalah dalam penelitian ini adalah (1). Bagaimana kondisi subjective well-being siswa siswa kelas X SMA Nuraida Islamic Boarding School Kota Bogor, (2) hubungan antara subjective well- being siswa dengan hasil belajar Biologi siswa kelas X SMA Nuraida Islamic Boarding School Kota Bogor.

Metode yang digunakan dalam penelitian ini adalah metode deskriptif kuantitatif dengan analisis korelasional. Penelitian ini dilakukan di SMA Nuraida Islamic Boarding School Kota Bogor dengan jumlah sampel sebanyak 46 orang, yang diambil dengan cara purposive sample. Analisis data yang digunakan adalah analisis regresi sederhana dan berganda.

Penelitian membuktikan bahwa : (1) Kondisi Subjective well-being siswa di SMA Nuraida Islamic Boarding School dalam kategori baik atau tinggi denga rata-rata skor komponen kepuasan hidup sebesar 3,98, (2) terdapat hubungan yang signifikan antara subjective well-being siswa dengan hasil belajar biologi siswa ditunjukan dengan hasil korelasi sebesar 0,490 dan koefisien determinasi sebesar 24,00\%.
\end{abstract}

Kata Kunci : $\quad$ subjective well-being, hasil belajar, biologi

\section{A. PENDAHULUAN}

Remaja yang akan memasuki lingkungan boarding school harus dapat menyesuaikan diri dengan kehidupan asrama, namun itu bukan suatu hal yang mudah bagi para remaja. Peralihan dari lingkungan keluarga ke lingkungan asrama akan menimbulkan perubahan yang signifikan bagi remaja. Perubahan yang terjadi pada diri dan lingkungan menuntut seorang remaja untuk melakukan penyesuaian diri, hal ini perlu dilakukan agar terjadi keselarasan antara pribadi remaja dengan

lingkungan asrama, sehingga remaja bisa dengan nyaman tinggal di lingkungan asrama Peserta didik di Nuraida Islamic Boarding School dipantau selama 24 jam penuh oleh musrifah (pendamping kamar). Peserta didik harus menghadapi orang yang sama dan lingkungan yang sama dengan dinamika kegiatan yang cenderung monoton setiap saat.
Sekolah berasrama memiliki tuntutan yang lebih tinggi jika dibanding sekolah non asrama. Disamping itu sekolah berasrama juga mengisolasi peserta didik dari lingkungan sosial dan membatasi pergaulan selama di dalam asrama. Banyak peserta didik yang mengikuti pendidikan dengan sistem sekolah berasrama karena kemauan dari orang tua bukan dari peserta didik itu sendiri

Aktivitas disekolah dan asrama yang cukup padat dan ruang gerak. kegiatan diasrama yang dibatasi dengan tata tertib yang ditetapkan oleh pihak asrama, dirasakan terlalu banyak dan mengekang oleh sebagian peserta didik, sehingga membuat para peserta didik merasa jenuh dan bosan tinggal di asrama. Kejenuhan yang dialami peserta didik sekolah berasrama turut mempengaruhi Subjective well-being peserta didik itu sendiri

Subjective well-being merupakan kondisi psikologis siswa di dalam merasakan kepuasan hidupnya yang dirasakan baik di 
dalam lingkungan keluarga, pergaulan, lingkungan sekolah maupun lingkungan belajar. Diener menyatakan bahwa suatu unsur dari kehidupan yang baik adalah bahwa individu itu menyukai kehidupannya, dimana individu yang dapat menikmati kehidupanya maka memiliki Subjective well-bein.Siswa yang memiliki Subjective well-being maka dapat dikatakan bahwa kondisi psikologis siswa tersebut menerima terhadap kepuasan hidup yang dijalaninya

Peserta didik yang merasa sejahtra dan puas serta mempersepsikan boarding school sebagai tempat yang menyenangkan akan lebih mampu dalam melakukan penyesuaian sosial. Sebaliknya, peserta didik yang mempersepsikan boarding school sebagai tempat yang tidak menyenangkan akan mengalami hambatan dalam melakukan penyesuaian sosial. Konsep sekolah berasrama diciptakan untuk meningkatkan mutu pendidikan yang diterima oleh para peserta didik melalui suatu sistem dengan karakteristik mengikat, keras, dan disertai sanksi tak jarang membuat peserta didik boarding school merasa terasing, tertekan dan tidak puas dengan sekolahnya. Peserta didik yang mampu mengembangkan sikap belajar yang positif, seperti perasaan suka, setuju dan senang terhadap aktivitas dan kegiatan belajar,maka hal tersebut akan berdampak positif juga terhadap pencapaian prestasi belajar siswa. Hal ini juga dibuktikan dari hasil penelitian yang dilakukan oleh Fara Hamdana yang mengatakan bahwa ada hubungan yang signifikan antara Subjective well-being siswa dengan prestasi belajar siswa.

\section{Subjective well-being}

Kebahagiaan bisa merujuk ke banyak arti seperti rasa senang (pleasure), kepuasan hidup, emosi positif, hidup bermakna, atau bisa juga merasakan kebermaknaan (contentment). Beberapa peneliti menggunakan istilah well-being sebagai istilah dari kebahagiaan (happiness) itu sendiri. Konsep well-being sendiri mengacu pada pengalaman dan fungsi psikologis secara optimal. Beberapa peneliti menulis kebahagiaan sebagai sinonim dari Subjective Wel-Being.
Menurut Carr Subjective well-being merupakan kondisi psikologis positif yang khas dengan tingginya tingkat kepuasan hidup, tingginya tingkat afeksi positif, serta rendahnya tingkat afeksi negatif. Sedangkan Diener, Luca, dan Oishi mendefinisikan subjective well being atau kesejahteraan subjektif sebagai hasil evaluasi atau penilaian seseorang secara kognitif dan afektif terhadap pengalaman hidup seseorang.

Sementara itu Diener berpendapat bahwa definisi dari Subjective well- being dan kebahagiaan dapat dibuat menjadi tiga kategori. Pertama, Subjective well-being bukanlah sebuah pernyataan subjektif tetapi merupakan beberapa keinginan berkualitas yang ingin dimiliki setiap orang. Kedua, Subjective well-being merupakan sebuah penilaian secara menyeluruh dari kehidupan seseorang yang merujuk pada berbagai macam kriteria. Arti ketiga dari Subjective well-being jika digunakan dalam percakapan sehari-hari yaitu dimana perasaan positif lebih besar daripada perasaan negatif. Sedangkan Campbell dalam Diener menyatakan bahwa

Subjective well-beingterletak pada pengalaman setiap individu yang merupakan pengukuran positif dan secara khas mencakup pada penilaian dari seluruh aspek kehidupan seseorang.

Diener mendefinisikan Subjective wellbeing sebagai penilaian global dari semua aspek kehidupan individu. Diener menterjemahkan Subjective well-being sebagai suatu bidang dalam ilmu perilaku mengenai evaluasi individu terhadap kehidupan yang dipelajarinya. Subjective well- being memiliki beragam konsep mulai dari suasana hati sebagai penilaian global terhadap kepuasan hidup, dan dari depresi ke euforia.

Compton menjelaskan Subjective wellbeing merupakan suatu proses kognitif individu mengenai penilaian yang global tentang penerimaan hidup individu. Compton berpendapat bahwa Subjective well-being terbagi dalam dua variabel utama: kebahagiaan dan kepuasan hidup. Kebahagiaan berkaitan dengan keadaan emosional individu dan bagaimana individu merasakan diri dan dunianya. Kepuasan hidup cenderung disebutkan sebagai penilaian 
global tentang kemampuan individu menerima hidupnya. Diener, dkk mengartikan Subjective well-being sebagai evaluasi kognitif dan afektif individu dari dirinya sendiri Evaluasi ini meliputi reaksi emosional terhadap kejadian serta penilaian kognitif terhadap kepuasan dan pemenuhan kebutuhan. Dengan demikian, Subjective well-being merupakan suatu konsep umum yang mencakup pengalaman emosi yang menyenangkan, rendahnya tingkat pengalaman negatif yang terdapat dalam tingkat Subjective well-being yang tinggi adalah konsep inti dari psikologi positif karena mereka membuat hidupnya bermanfaat.

Pavot dan Diener dalam Linley dan Joseph berpendapat (2004: 680) Subjective well-beingmewakili penilaian seseorang terhadap diri mereka sendiri, dan penilaian tersebut dapat berdasarkan kepada respon kognitif (teori) dan emosional. Penilaian seperti itu adalah informasi pokok dalam menentukan kualitas hidup dan kepuasan (well-being) seseorang secara keseluruhan, tetapi tidak cukup untuk menyebabkan kualitas hidup yang baik jika elemen dasar dari martabat dan kebebasan manusia tidak ada.

Subjective well-being melibatkan evaluasi multidimensional kehidupan, termasuk penilaian kognitif dari kepuasan hidup dan evaluasi afektif emosi dan suasana hati. Area Subjective well-being terdiri dari analisis ilmiah tentang bagaimana individu mengevaluasi kehidupan individu tentang suatu peristiwa, suasana hati, penilaian mereka tentang bentuk kepuasan hidup, pemenuhan kebutuhan kepuasan pada domain seperti pernikahan dan pekerjaan.

Subjective well-being adalah penilaian individu terhadap kehidupan yang positive dan berjalan dengan baik. Individu dikatakan memiliki Subjective well-being tinggi jika individu tersebut memiliki kepuasan hidup dan lebih sering merasakan kebahagiaan, serta jarang mengalami emosi yang tidak menyenangkan sepertikesedihan atau kemarahan. Sebaliknya, individu dikatakan memiliki Subjective well-being rendah jika individu merasa tidak puas dengan kehidupannya, mengalami sedikit kebahagiaan dan kasih sayang serta lebih sering merasakan emosi yang negatif seperti kemarahan atau kecemasan. Berdasarkan beberapa pengertian di atas, maka dapat disimpulkan bahwa Subjective well-being adalah suatu penilaian umum individu yang meliputi berbagai aspek terhadap kehidupannya yang penuh dengan kepuasan dan kebahagiaan sehingga individu mampu merasakan emosi yang positif dan sedikit emosi yang negatif.

\section{Hasil Belajar Biologi}

Proses belajar yang telah dilalui oleh setiap individu atau manusia, selalu berujung pada hasil. Karena suatu proses dapat dikatakan ada jika ada suatu yang dapat dihasilkan dari hasil proses belajar. Untuk lebih jelasnya tentang hasil belajar secara ilmiah, dengan ini penulis akan paparkan beberapa pengertian hasil belajar menurut para ahli.

Untuk memberikan pengertian tentang hasil belajar maka akan diuraikan terlebih dahulu dari segi bahasa. Pengertian ini terdiri dari dua kata 'hasil' dan 'belajar'. Dalam KBBI hasil memiliki beberapa arti: 1) Sesuatu yang diadakan oleh usaha, 2) pendapatan; perolehan; buah. Sedangkan belajar adalah perubahan tingkah laku atau tanggapan yang disebabkan oleh pengalaman. Adapun yang dimaksud dengan belajar menurut Usman adalah "Perubahan tingkah laku pada diri individu berkat adanya interaksi antara satu individu dengan individu lainnya dan antara individu dengan lingkungan".

Hasil belajar merupakan kemampuan yang diperoleh individu setelah proses belajar berlangsung, yang dapat memberikan perubahan tingkah laku baik pengetahuan, pemahaman, sikap dan keterampilan siswa sehingga menjadi lebih baik dari sebelumnya. Hasil belajar merupakan salah satu indikator dari proses belajar. Hasil belajar adalah perubahan perilaku uyang diperoleh siswa setelah mengalami aktivitas belajar. Salah satu indikator tercapai atau tidaknya suatu proses pembelajaran adalah dengan melihat hasil belajar yang dicapai oleh siswa. Menurut Sudjana mendefinisikan hasil belajar siswa pada hakikatnya adalah perubahan tingkah laku sebagai hasil belajar dalam pengertian yang lebih luas mencakup bidang kognitif, afektif dan psikomotor". 
Hasil belajar merupakan tingkat penguasaan yang dicapai oleh siswa dalam mengikuti program belajar mengajar, sesuai dengan tujuan yang ditetapkan. Menurut Dimyati dan Mudjiono, dapat dipahami bahwa yang dimaksud dengan hasil belajar merupakan suatu proses untuk melihat sejauh mana siswa dapat menguasai pembelajaran setelah mengikuti kegiatan proses belajar mengajar, atau keberhasilan yang dicapai seorang peserta didik setelah mengikuti kegiatan pembelajaran yang ditandai dengan bentuk angka, huruf, atau simbol tertentu yang disepakati oleh pihak penyelenggara pendidikan.

Dari beberapa teori di atas tentang hasil belajar, dapat disimpulkan oleh penulis bahwa hasil belajar merupakan hasil perubahan tingkah laku yang meliputi kognitif, afektif dan psikomotorik, setelah selesai mengikuti proses pembelajaran yang dibuktikan dengan hasil evaluasi yang dinyatakan dalam simbolangka, huruf maupun kalimat. Hasil belajar dapat merupakan suatu indicator keberhasilan siswa di dalam mengikuti proses pembelajaran apakah berhasil dengan baik, cukup ataukah kurang

Menurut Riana Yani dkk mengatakan bahwa "biologi merupakan cabang sains yang mempelajari tentang seluk beluk makhluk hidup. Biologi berasal dari bahasa Yunani yang terdiri dari dua kata yaitu Bios yang berarti hidup dan logis yang berarti ilmu". Masih menurut Riana Yani belajar Biologi merupakan upaya mengenali diri sendiri sebagai makhluk karena pada dasarnya manusia selalu tertarik pada dirinya sendiri, organisme lain dan juga lingkungan sekitar.

Terkait dengan paparan sebelumnya yang telah diulas oleh penulis bahwa hasil belajar merupakan perubahan tingkah laku yang ada pada diri siswa baik yang mencakup dari aspek kognitif, afektif maupun psikomotor di dalam mempelajari sesuatu. Hasil belajar biologi pada hakikatnya siswa diharapkan mampu memahami, mengeksplor, mencoba dan menyimpulkan fenomenafenomena yang terjadi di dalam kehidupan sehari-hari yang dikaitkan dengan biologi, seperti pengetahuan tentang hakikat biologi, pengembangan sel, virus, mikroba dan lainnya.
Berdasarkan paparan pendapat di atas, dapat disimpulkan bahwa hakikat hasil belajar biologi di tingkat SMA merupakan proses tindak lanjut pembelajaran dari tingkat SMP, yang mempelajari tentang fenomena alam dan lingkungan di dalam kehidupan sehari-hari, dimanaproses pembelajaran tersebut ditekankan pada terciptanya interaksi antara siswa dengan objek yang dipelajarinya, sehingga siswa dapat mengeksplor, memahami dan merasakan, menemukan konsep dan memberikan kesimpulan atas apa yang tejadi dari hasil yang dipelajarinya. Oleh karena itu, siswa dituntut untuk mengikutsertakan Kecerdasan Intelektual yang dimilikinya untuk menarik kesimpulan atas proses pembelajaran biologi yang dilakukan di dalam kelas.

\section{B. METODOLOGI PENELITIAN}

Penelitian ini menggunakan metode deskriptif kuantitatif dengan analisis korelasional, maksud menggunakan metode ini yaitu untuk mendeskripsikan berdasarkan fakta dan kejadian sebenarnya dari tempat penelitian yang dikaitkan dengan teori-teori serta asumsi-asumsi yang ada.

Dalam penelitian ini jumlah total populasi siswa Nuraida Islamic Boarding School berjumlah 69 orang siswa. SMA Nuraida Islamic Boarding School ini baru mulai beroperasi pada Tahun Pelajaran 2018/2019, dengan jumlah total siswa yang diterima sebanyak 69 orang siswa. Sebagai subjek penelitian ini, penulis mengambil sampel dengan cara purposive sample, yaitu sampel yang diambil secara khusus dan bertujuan. Sampel yang dijadikan sebagai objek dalam penelitian ini yaitu khusus siswa kelas IPA yang berjumlah 46 siswa, yang terdiri dari kelas XA sebanyak 23 siswa dan kelas $\mathrm{Xb}$ sebanyak 23 siswa. Sampel ini diambil berdasarkan pendapat yang dikemukakan oleh Zainal Abidin Arief "Suatu hal yang perlu dicatat adalah bahwa pengambilan sampel secara random dapat digunakan apabila unit-unit elementer dalam populasi mempunyai karakteristik yang homogen dan dapat dianggap homogen.

Penelitian ini menggunakan data primer, yang diperoleh melalui penelitian langsung terhadap obyek yang diteliti dengan cara melakukan pengamatan langsung dan 
memberikan kuesioner kepada siswa (peserta didik) dan serta menggali informasi kepada pihak-pihak yang terlibat dengan masalah yang sedang dibahas. Untuk mendukung keakuratan dalam pengumpulan data ini, penulis melakukan dengan cara studi kepustakaan dan riset lapangan.

Instrumen dalam penelitian ini terdiri dari Subjective well-being, dengan memberikan pertanyaan masing-masing diberikan bobot penilaian dengan model skala likert.Skala Likert digunakan untuk mengukur sikap, pendapat, dan persepsi seseorang atau sekelompok orang tentang fenomena social. Kuesioner dalam penelitian ini menggunakan lima pilihan jawaban. Cara responden menjawab pertanyaan dengan memberikan tanda cheklis $(\sqrt{ })$ pada salah satu alternatif jawaban yang telah disediakan. Adapun alternatif jawaban dan bobot skor jawaban dapat dilihat pada tabel di bawah ini:

Tabel 1 Skala Pengukuran data Kuesioner

\begin{tabular}{|l|c|c|c|}
\hline \multicolumn{1}{|c|}{ Pilihan Jawaban } & Kode & Skor & Makna \\
\hline Sangat Setuju & SS & 5 & Sangat Tinggi \\
\hline Setuju & S & 4 & Tinggi \\
\hline Kurang Setuju & KS & 3 & Sedang \\
\hline Tidak Setuju & TS & 2 & Rendah \\
\hline Sangat Tidak Setuju & STS & 1 & Sangat Rendah \\
\hline
\end{tabular}

Hasil belajar Biologi siswa dalam penelitian ini diperoleh dari hasil nilai ratarata ulangan harian Ke-I, ulangan harian ke-2 dan nilai UAS, pada semester ganjil tahun pelajaran 2018/2019. Nilai rata-rata tersebut kemudian diolah untuk dijadikan sebagai alat penelitian variabel hasil belajar siswa pada mata pelajaran Biologi.

\section{HASIL DAN PEMBAHASAN}

\section{Pengujian Validitas Realibilitas dan Normalitas Data}

Sebelum dilakukan analisis untuk menjawab rumusan masalah dan hipotesis penelitian, alat ukur yang digunakan dalam penelitian ini sebelumnya akan diuji tingkat reliabilitas dan validitas itemnya.

Berdasarkan hasil uji reliabilitas data dengan menggunakan program bantuan SPSS versi 22, diperoleh nilai alpha cronbach sebesar 0,855. (Sumber : Hasil olah data validitas dengan SPSS). Dari hasil uji reliabilitas menunjukkan bahwa untuk variabel hasil belajar biologidapat dikatakan reliabel, karena nilai alpha cronbachs > 0,60Berdasarkan hasil uji reliabilitas data dengan menggunakan program bantuan SPSS versi 22, diperoleh nilai alpha cronbach sebesar 0,692 (Sumber : Hasil olah data validitas dengan SPSS). Dari hasil uji reliabilitas menunjukkan bahwa untuk variabel Subjective well-being dapat dikatakan reliabel, karena nilai alpha cronbachs $>0,60$.

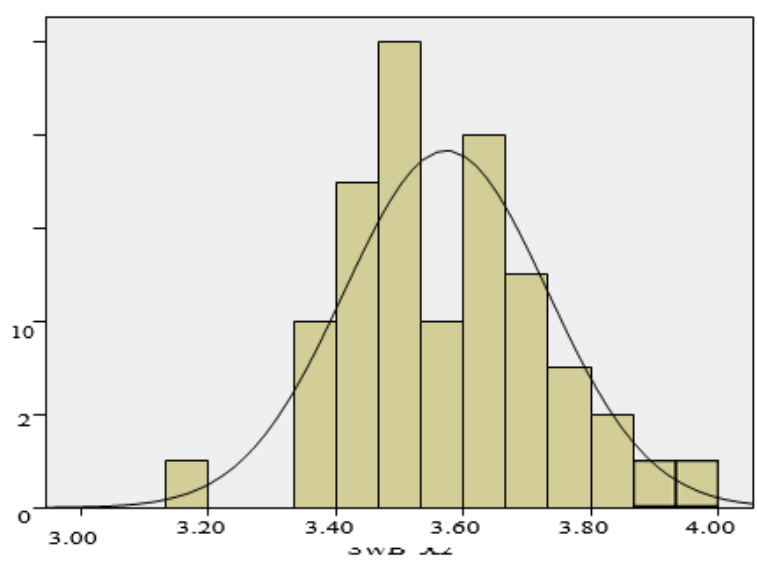

Gambar 2 Histogram Normalitas Data Variabel Subjective well-being

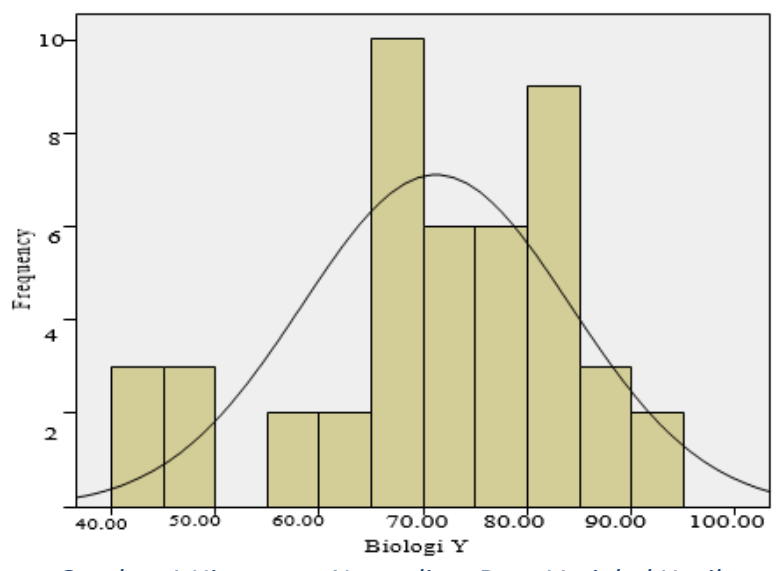

Gambar 1 Histogram Normalitas Data Variabel Hasil Belajar Biologi

Berdasarkan hasil uji normalitas data dari gambar-gambar kurva di atas, menunjukkan bahwa bentuk kurva berada di tengah-tengah, hal ini menandakan bahwa semua variabel dalam penelitian ini berdistribusi normal. 


\section{Pengujian Hipotesis}

Untuk menguji hubungan antara variabel Subjective well-being (X) dengan hasil belajar Biologi (Y) dapat diketahui dari hasil perhitungan yang telah dilakukan dengan program bantuan SPSS versi 22 sebagai berikut :

Coefficient ${ }^{\mathrm{a}} \mathrm{s}$

\begin{tabular}{|c|r|r|c|c|c|}
\hline & \multicolumn{2}{|c|}{$\begin{array}{c}\text { Unstandardized } \\
\text { Coefficients }\end{array}$} & $\begin{array}{c}\text { Standardized } \\
\text { Coefficients }\end{array}$ & $\mathrm{t}$ & Sig. \\
\cline { 2 - 6 } Model & $\mathrm{B}$ & Std. Error & Beta & & \\
\hline 1 Constant & -70.480 & 38.067 & & -1.851 & .071 \\
SWB_X2 & 39.655 & 10.644 & .490 & 3.726 & .001 \\
\hline
\end{tabular}

Dependent Variable: Biologi_Y

Dari data tabel di atas terlihat bahwa hasil nilai t-hitung sebesar 3,726 dengan tingkat sig 0,001 . Nilai t-tabel pada 0,05 dengan $\mathrm{df}=\mathrm{n}-2=46-2=44$ diperoleh nilai $\mathrm{t}$ tabel sebesar 2,0154. Hasil t-hitung 3,726 > ttabel 2,0154 dengan sig 0,05>0,001 yang artinya bahwa hipotesis yang diajukan diterima. Hal ini berarti bahwa terdapat hubungan yang signifikan antara Subjective well-being dengan hasil belajar Biologi siswa.

Besarnya nilai korelasi atau hubungan antara variabel Subjective well-being (X) dengan variabel hasil belajar Biologi siswa (Y) dapat dilihat pada tabel berikut ini:

\begin{tabular}{|l|r|r|l|l|}
\hline Model & Rodel Summary \\
\hline 1 & $.490^{\mathrm{a}}$ & .240 & .223 & 11.37715 \\
\hline
\end{tabular}
a. Predictors: (Constant), SWB_X2
b. Dependent Variable: Biologi_Y
R. Square

Besarnya nilai koefisien korelasi (rxy2) hubungan antara Subjective well-being terhadap hasil belajar Biologi sebesar 0,490 dan besarnya nilai koefisien determinasi atau pengaruh yang diberikan variabel Subjective well-being terhadap hasil belajar Biologi sebesar 24,00\%. Model persamaan regresi antara variabel Subjective Well Being (X) terhadap hasil belajar Biologi Siswa (Y) diperoleh persamaan regresi dengan rumus $\grave{Y}=\alpha+\beta_{1} X_{1}$, yaitu $\grave{Y}=-70,480+39,655 X$, persamaan regresi ini mengandung arti :

Nilai konstanta sebesar $-70,480$ menyatakan bahwa jika nilai variabel Subjective well-being tidak ada (0), maka nilai variabel hasil belajar Biologi sebesar $-70,480$

Koefisien regresi variabel Subjectiv wellbeing sebesar 39,655 mengandung arti bahwa setiap penambahan 1 (satu) poin variabel Subjective well-being maka akan meningkatkan hasil belajar Biologi sebesar 39,655 kali

Intepretasi dari persamaan di atas adalah koefisien regresi variabel Subjective wellbeing memiliki tanda positif $(39,655)$ hal ini mengandung arti bahwa Subjective well-being siswa searah dengan variabel hasil belajar Biologi

Dari hasil deskriptif statistic nilai minimum rata-rata jawaban responden yaitu sebesar 3,16, dan nilai maksimum rata-rata jawaban responden sebesar 4,00, dan nilai rata-rata dari keseluruhan jawaban responden adalah 3,57. Nilai rentang mean 3,57 jawaban responden dapat dikatakan baik, karena nilai rata- rata berada pada kisaran 3-4.

Hasil uji t-tes diperoleh bahwa hasil thitung 3,726>t-tabel 2,0154 hal ini mengindikasikan bahwa terdapat hubungan yang signifikan antara Subjective well-being siswa dengan hasil belajar Biologi. Besar nilai korelasi rxy2 yaitu 0,490 , nilai korelasi ini berada pada rentang korelasi atau hubungan yang sedang atau cukup.

Untuk instrument variabel Subjective well-being dalam penelitian ini adalah berupa kuesioner yang terbagi menjadi 3 (tiga) indicator yaitu 1) kepuasan hidup, 2) afeksi positif dan 3 afeksi negative. Dari ketiga indicator tersebut diperoleh rata-rata jawaban responden yaitu 3,98 untuk komponen kepuasan hidup; untuk komponen afeksi positif siswa diperoleh skor rata-rata jawaban responden 3,91; dan afeksi negative siswa diperoleh skor rata-rata jawaban responden 2,74 .

Rata-rata skor komponen kepuasan hidup sebesar 3,98, hal ini menandakan bahwa skor rata-rata jawaban responden bernilai atau bermakna tinggi. Skor tersebut mengindikasikan bahwa, komponen kepuasan hidup siswa SMA Nuraida Islamic Boarding School mempunyai rasa kepuasan hidup yang tinggi. Siswa merasa hidup nyaman dengan kondisi saat ini, baik kondisi keluarga, lingkungan sekolah dan teman pergaulan, 
serta merasa nyaman dan puas dengan kondisi yang ada pada diri siswa.

Skor rata-rata komponen afeksi positif siswa yaitu sebesar 3,91, hal ini juga menandakan bahwa faktor afeksi positif atau rasa emosi yang dimiliki oleh siswa SMA Nuraida Islamic Boarding School mempunyai afeksi positif yang tinggi, artinya emosi siswa stabil dan dapat mengendalikan kearah halhal yang positif.

Skor rata-rata komponen afeksi negativesiswa yaitu sebesar 2,74, skor ini berada pada nilai rendah, hal ini menandakan bahwa afeksi negative atau perasaan negative siswa di SMA Nuraida Islamic Boarding School berada pada level rendah, artinya siswa masih dapat mengendalikan halhal/sikap yang negative yang muncul ataupun yang dimiliki dalam diri siswa

Dari hasil jawaban responden tersebut di atas, dapat disimpulkan bahwa Subjective well-being siswa di SMA Nuraida Islamic Boarding School dalam kategori baik atau tinggi. Artinya secara umum para siswa di SMA Nuraida Islamic Boarding School memiliki rasa kepuasan hidup yang nyaman, bahagia serta jarang mengalami emosi-emosi yang berlebihan. Individu yang memiliki rasa Subjective well-being yang tinggi akan memiliki semangat dalam menjalani hidupnya, namun sebaliknya jika individu atau siswa yang memiliki Subjective wellbeing yang rendah maka individu atau siswa itu tidak memiliki semangat hidup, namun hidupnya penuh dengan rasa emosi yang rendah dan tidak dapat dikendalikan.

\section{KESIMPULAN DAN SARAN}

\section{Kesimpulan}

Dari hasil penelitian yang telah dilakukan, dapat diambil beberapa kesimpulan yang sesuai dengan tujuan penelitian, yaitu sebagai berikut:

1. Kondisi Subjective well-being siswa di SMA Nuraida Islamic Boarding School dalam kategori baik atau tinggi. Artinya secara umum para siswa di SMA Nuraida Islamic Boarding School memiliki rasa kepuasan hidup yang nyaman, bahagia serta jarang mengalami emosi-emosi yang berlebihan

2. Terdapat hubungan yang signifikan antara Subjective well-being terhadap hasil belajar Biologi siswa di SMA Nuraida Islamic Boarding School kota Bogor.

\section{Saran}

Saran-saran yang dapat diajukan dalam penelitian ini sebagai berikut:

1. Sekolah harus memberikan sarana dan prasarana yang memadai dalam penyelenggaraan proses belajar mengajar dan menciptakan suasana yang kondusif dalam lingkungan sekolah, sehingga siswa merasakan kenyamanan di dalam menuntut ilmu.

2. Siswa hendaknya bersifat terbuka jika ada permasalahan yang ingin diungkapkan baik kepada teman yang dipercaya, kepada guru ataupun kepada orang tua, agar mendapatkan solusi yang terbaik.

3. Orang Tua Siswa selalu memberikan perhatian dengan melakukan komunikasi secara berkala kepada putri-putrinya dan memberikan motivasi kepada putrinya di dalam menuntut ilmu di SMA Nuraida Islamic Boarding School.

\section{DAFTAR PUSTAKA}

Abidin Arief, Zainal. Kawasan Penelitian

Teknologi Pendidikan. Bogor: UIKA

Press. 2017.

Ahmad, Sutrisno, dkk. Psikologi Pendidikan, (Gontor: Pondok Modern Darussalam

Gontor, 2015

Agung, Iskandar. Panduan Penelitian

Tindakan Kelas Bagi Guru. Jakarta:

Bestari, 2012.

Azwar, Saifuddin. Psikologi Intelegensi.

Yogyakarta: Pustaka Pelajar. 2002. Pengantar Psikologi Intelegensi.

Yogyakarta: Pustaka Pelajar. 1996.

Compton, William C. Introduction to

Positive Psychology. USA: Thomson

Learning Inc. 2005.

Davidoff, Linda L. Psikologi Suatu

Pengantar. Jakarta: Erlangga. 2000 
Dimyati dan Mudjiono, Belajar dan

Pembelajaran. Jakarta: Rineka Cipta. 2013

Djamarah, Syaiful Bahri. Psikologi Belajar. Jakarta: Rineka Cipta. 2011.

Ed Diener. Psychological Bulletin. American Pschological Association Inc. 1984. Vol. 95.

Ed Diener. Subjective well-being: The Science of Happiness and a Proposal for a National Index. USA: American Psychologist. 2000.

Ed Diener. Oishi \& Lucas R.E. Subjective well- being: The Science of Happiness and life Satisfaction. In S.J. Lopez \& CR Snyder (Eds). Oxford Handbook of Positive Psychology. New York: Oxford University Press.

Eid, M, and Diener. Culture and Subjective well-being.USA: MIT. 2000.

Hasan, Chalijah. Dimensi-Dimensi Psikologi Pendidikan. Surabaya: Al-Ikhlas. 1994. Hanggoro, Yohanes Tri Pamungkas. Penelitian Deskriptif: Subjective wellbeing pada Biarawati Yogyakarta. Yogyakarta: Universitas Sanata Dharma. 2015

Irwanto. Psikologi Umum. Jakarta: PT. Prenhalindo. 2002.

Iskandar. Psikologi Pendidikan,Jakarta: Referensi. 2012

Islamudin, Haryu. Psikologi Pendidikan. Yogyakarta: Pustaka Belajar. 2012.

Irwanto. Psikologi Umum. Jakarta: PT. Prenhalindo. 2002.

Joko Yunanto, Sri. Sumber Belajar Anak Cerdas. Jakarta: PT. Raja Grafindo. 2004.

Linley, P.A. \& Joseph S. Positive Psychology in Practice.New York: Wiley. 2004.

Mardianto.Psikologi Pendidikan. Medan: Perdana Publishing. 2012.
Mulyasa, E. Kurikulum Tingkat Satuan

Pendidikan. Bandung: PT. Remaja

Rosdakarya. 2006

Mustakim.Psikologi Pendidikan.

Yogyakarta: Pustaka Belajar Offset.

2004.

Nurkancana, Wayan. Dan Suwartana.

Evaluasi Pendidikan. Surabaya: Usaha

Nasional. 2002.

Prawirohartono, Slamet dan Sri

Hidayati.Sains Biologi 2

SMA/MA/Kelas XII.Jakarta: PT. Bumi

Aksara. 2007

Rahayu, Ika Kurnia. Kesejahteraan Subjectif

(Subjective well being) pada istri

Narapidana sekaligus Penderita Kanker

Ovarium, Malang: UIN Maulana Malik Ibrahim, 2015.

Sabri, M. Alisuf, Psikologi Pendidikan.

Jakarta: Pedoman Ilmu Jaya. 2010

Sardiman AM,Interaksi dan Motivasi

Belajar- Mengajar. Jakarta: PT. Raja

Grafindo Persada. 2014.

Sobur, Alex. Psikologi Umum. Bandung: CV

Pustaka Setia. 2009.

Slameto, Belajar dan Faktor-Faktor yang

Mempengaruhi. Jakarta: PT Asdi

Mahasatya. 2003.

Sudjana, Nana.Penilaian Hasil Proses Belajar

Mengajar, Bandung: PT Remaja

Rosdakarya. 2010

Suhardi.Diktat Persoalan Sumber Belajar

Biologi.Yogyakarta: FMIPA UNY.

2011

Sujanto, Agus. Psikologi Umum. Jakarta:

Bumi Aksara. 1993.

Surya Subrata, Sumadi. Psikologi

Pendidikan. Jakarta: Raja Grafindo

Persada. 1995.

Suryabrata, Sumadi. Psikologi Pendidikan. Jakarta: PT. Raja Grafindo Persada. 1998. 
Su'udah, Fauzik Lendriyono. Pengantar Psikologi. Jakarta: Gramedia. 2010

Syah, Muhibbin. Psikologi Belajar. Jakarta: Bumi Aksara. 2011

Tim Penyusun Pusat Bahasa (Mendikbud). Kamus Besar Bahasa Indonesia. Jakarta: Balai Pustaka. 2007.

Toha, Chabib. Kapita Selekta Pendidikan Islam.Yogyakarta: Pustaka Pelajar. 2007.

Triyanto. Model Pembelajaran Terpadu. Jakarta: Bumi Aksara. 2010.

Uno B, Hamzah. Orientasi Baru dalam Psikologi Pembelajaran.Jakarta: PT. Bumi Aksara. 2006.

Uzer Usman, Muhammad. Menjadi Guru Profesional.Bandung: Remaja Rosdakarya. 2000.

Whitherington.Psikologi Pendidiakn. Jakarta: PT. Rineka Cipta. 1991.

Yani, Riana, Musarofah dan Tintin Atikah dkk. Biologi 1 Kelas X SMA dan MA, Jakarta: Pusat Perbukuan Departemen Pendidikan Nasional. 2009. . Biologi 1 Kelas X SMA dan MA, Bandung: PT Remaja Rosdakarya. 2007.

Here, Sonia Visita dan Pius Heru Priyanto. Subjective Well Being pada Remaja ditinjau dari Kesadaran Lingkungan, (Yogyakarta: Jurnal Psikodimensia, Vol 13 No 1 Januari-Juni 2014, 10-21) hlm 12

Nickyta Sari, Primiadiati. Hubungan Status Gizi dengan Tigkat Kecerdasan Intelektual (Intelegence Quetient-IQ) pada anak Usia Sekolah Dasar ditinjau dari Status Sosial Ekonomi orang tua dan Tingkat Pendidikan Ibu, (Surakarta: Fakultas Kedokteran Universitas Sebelas Maret, 2010) 